Datu et al., 2019

Volume 5 Issue 1, pp. 69-80

Date of Publication: 15 ${ }^{\text {th }}$ March 2019

DOI-https://dx.doi.org/10.20319/pijss.2019.51.6980

This paper can be cited as: Datu, Y. A., Limantara, S. W., Soelistiyowati, E., Hardjanto, T. D. E Fuadi, Y. (2019). The Design of TBECC (Test of Business English Communication Competence) for Front Office Staff in Hotel Industry: A Case Study of Hotels in Surabaya, Indonesia. PEOPLE: International Journal of Social Sciences, 5(1), 69-80.

This work is licensed under the Creative Commons Attribution-Non Commercial 4.0 International License. To view a copy of this license, visit http://creativecommons.org/licenses/by-nc/4.0/ or send a letter to Creative Commons, PO Box 1866, Mountain View, CA 94042, USA.

\title{
THE DESIGN OF TBECC (TEST OF BUSINESS ENGLISH COMMUNICATION COMPETENCE) FOR FRONT OFFICE STAFF IN HOTEL INDUSTRY: A CASE STUDY OF HOTELS IN SURABAYA, INDONESIA
}

\author{
Yerly A. Datu \\ Politeknik Ubaya, Indonesia \\ yerly@staff.ubaya.ac.id

\section{Singgih Widodo Limantara \\ Politeknik Ubaya, Indonesia \\ ngagel2015@gmail.com} \\ Endang Soelistiyowati \\ Sekolah Vokasi UGM, Yogyakarta \\ endang_soelistiyowati@ugm.ac.id
}

Tofan Dwi Hardjanto

FIB UGM, Yogyakarta

deha@ugm.ac.id

Yusron Fuadi

Sekolah Vokasi UGM, Yogyakarta

yusron.fuadi@ugm.ac.id

\begin{abstract}
Competition among hospitality industries in Indonesia has come to inevitable battle and, therefore, they must strengthen their front-liner staff for exemplary service due to the fact of the increasing numbers of hotels every year particularly in Surabaya, the capital of East Java Province and its role both for tourism and business. The role resulted in wave of expatriates coming to Surabaya and therefore strong English communication is considered important.
\end{abstract}


Initial survey showed that specific English test for Front Office (FO) staff recruitment in hotels did not exactly exist. For this purpose, a qualitative research employing a case study approach was conducted. The research involved 8 hotels in Surabaya and 40 participants comprising hotel leaders and FO staff. The important stages were conducted such as conducting Focus Group Discussion (FGD) with hotel leaders, distributing a set of questionnaire to Front Office leaders and staff, as well as enhancing clarity and confirmation through interviews. From those stages, the writer formulated the Target Language Use (TLU) of Front Office Division as basis to construct the Test of Business English Communication Competence (TBECC). Results showed that at least 18 of 26 items were extracted as TLUs for speaking and 7 of 10 items were extracted to serve as TLUs for writing. Finally, based on the obtained TLUs, 14 questions for speaking were constructed and for writing test, 5 questions measured competencies such as filling a guest detailed form, writing a confirmation letter, welcome letter and email of coordination, as well as replying a complaint and writing a thank you email to guests. Finally, recommendation to involve more hotels that receive a huge number of foreigners as their guests was also given.

\section{Keywords}

Hotel, Speaking, Writing Target Language Use (TLU), Test of Business English Communication Competence (TBECC), Front Office

\section{Introduction}

Surabaya, as the central city of East Java Province in Indonesia, has rapidly grown its economic condition for the past decade. Such condition occurs ever since the city is acknowledged as one the biggest center of business in the region. Conducive environment has also been successfully developed by the local government through the establishment of better transportation, new airport, and terminals for public. Consequently, there are many positive impacts earned by the city. More people from outside Surabaya invest their money and do business in this city. New businesses at least are created due to its attraction as a promising city which later, in turn, can return their capital a lot more than invested in the future. Not only as a center of business in East Java, Surabaya has also developed its tourism to increase local revenue. Realizing the prospects, the local government has also done tremendous efforts in shaping Surabaya as a tourist destination which offers culinary asset at the same time. In addition, such amazing developments in Surabaya has brought individuals not only from other regions in Indonesia but also foreign ones to stay both temporarily and permanently. 
Huge wave of people from outside Surabaya coming to this city along with its growing business and tourism, without doubts, lead to the demands of hotels for them. Indonesia Hotel and Restaurant Association (IHRA) claims potential number of hotels keep on increasing year by year. At least, the association notes hotels grow up to 10 percent in average from 2016 to 2017. Though number of hotels has been continuously improving, average occupancy rate is not always parallel to it. Therefore, tight competition becomes inevitable especially on products and services. Competitive rates on hotel rooms, different facilities offered, better services than others given to customers and the like show how the competition has taken place.

Services in hospitality industry, in this regard, are closely related to the capacity of human resources at hotels that deal directly with customers. Seeing the fact that Surabaya is widely open for foreigners who come for business or leisure, English competence should be acquired by the Front Office (FO) staff as the front lines serving the overseas guests. In the preliminary observation and interview involving three and four star hotels in Surabaya conducted, it was found out that all of them shared one common problem; their staff's English competence both oral and written. In the interview, Hotel supervisors and managers claimed that there was an urgent need to improve their staff's speaking and writing competence for the purpose of excellent service in hospitality industries and seemed that . Smooth communication between the customers and staff for the sake of the fulfilment of needs during their stay in the hotels was the important issue to address. In short, as long as the foreign customers can get what they need quickly, hotel service would be scored "good" or even "excellent". Thus, the ability to respond both in oral and written method became the focus in hotel business.

The competence of oral and written English in Front Office Division becomes the substantial need which should be fulfilled and this becomes matters for those who want to be part of the team as Mountford's claim (1981) about needs as knowledge which should be learnt by learners since they are considered important by the company. The knowledge the applicants learn becomes requirements in order to be successful at job finding (Widdowson, 1981). In the case of matching the needs of the company, there should be match between employment skills and job requirements (Betchoo, N.K., 2017). Moreover, Hutchinson and Waters (1996) point out the English language as the requirement in target situation, in this case, Front Office Division at Hotels.

In regard with competence which should be owned by the applicants, language competence was one of the elements of employability that belonged to the competitiveness of 
indicators of soft skills, hard skills and competitiveness (SHC) performances (Hadiyanto, et al., 2017). These components come to the Hard skills category. Meanwhile, in the soft skills element, communication skills also becomes an important indicator of SHC performances since it involves the ability of using English both oral and written one.

Due to its importance, another finding from the interview was that these hotels had not had proper test to check the applicants' English competence. They claimed oral interview was the only way to check their speaking interview, meanwhile, writing competence referred to their application letters or curriculum vitae (CV). Interview session mostly asked about general information of the applicants which include; educational background, reason applying the position, and efforts to be considered eligible for the position. Length of interview varied from ten to thirty minutes. Finally, the interviewer decided the fitness of the applicants on the basis only from their interview and CV.

\section{Problem Identification}

From the process of interview and screening applicants' CV, the main problem can be identified that the process did not really measure speaking and writing ability relevant to the Front Office (FO) tasks on daily basis. Due to the fact, hotels did not have a specific test that can be used for staff recruitment of Front Office Department.

\section{Research Objectives}

Finding out the fact hotels did not have proper speaking and writing test for Front Office (FO), the writer intended to create a test which could measure the candidates' speaking and writing competence applying for FO positions. Since the test is intended to measure communication competence in business field particularly hotel business, this research aimed at:

a. Describing stages of test construction intended to Front Office competence;

b. Drawing Target Language Use (TLU) for both speaking and writing;

c. Designing a Test of Business English Competence (TBECC).

\section{Method}

Test of Business English Communication Competence (TBECC) was designed based on some important stages conducted. They are:

- Document and library study

As basis to design the test, the writer collected relevant documents which could support as reference. The first document referred to a survey conducted by the 
Business English Study Program of Politeknik Ubaya, Surabaya, East Java, in 2016. The survey involved companies where students of Business English conducted apprenticeship. Findings showed users expected the curriculum of Business English focused more on speaking and writing as the needed competence at the time. Another research by Datu (2016) involved sixteen vocational high schools and eighty five participants in Surabaya and Sidoarjo revealed that (1) low confidence level of the participants to speak English, (2) low level of speaking ability of the participants, and (3) participants' poor exposure of English. Datu and Rachmasari (2016) also addressed similar issues like low confidence level as well as poor speaking competence perceived by the participants involving those who took Public Speaking Subject.

Relevant to the above studies, Sekolah Vokasi Universitas Gadjah Mada (SVUGM), Jogjakarta, Central Java, designed a test called TEVocS (Test of English for Vocational Students) in 2016. The test covered the four skills namely Speaking, Listening, Reading and Writing. Inputs for the test from companies were in regard with the addition of items for writing and reading competence, more various items in speaking and listening (Soelistywati, E., \& Yuanti, E. E., 2016).

- Field study

In this part, the process was divided into three stages namely Focus Group Discussion (FGD), distributing a set of questionnaire and interview. The FGD involved forty participants from eight different hotels in Surabaya, Indonesia. The profile of the hotels were two five-star hotels, four four-star hotels and two three-star hotels. The participants in FGD consisted of hotel leaders and Front Office staff. In this stage, the writer did need analysis to obtain information on tasks usually performed by the FO staff (Ellis and Johnson, 1994). The effort was systematically done since it dealt with the hotel system as suggested by Graves (2000) in defining need analysis.

For the second stage, the writer also distributed questionnaire to all participants comprising Front Office staff and managers. The purpose was to obtain the Target Language Use (TLU) which became the basis of constructing Test of Business English Communication Competence (TBECC). This process became thenext-step process of needs analysis which identified more specific language needs at the FO Division (Richards, J. C., P, T., \& P, N., 1992). 
The last stage was to conduct interview as a means of clarifying or reconfirming what had been uttered during FGD and written in the questionnaire. All information from FGD, questionnaire and interview were then analysed and extracted the language needs into TLU for the two skills; speaking and writing.

\section{Results and Discussions}

FGD and survey were conducted in eight hotels. During FGD, hotel leaders were invited to get information on which department that used English competence the most frequent and kind of situations that FO staff usually used English in their day-to-day operations. To strengthen the findings in FGD, questionnaires were also distributed to forty respondents from those eight hotels. The respondents were all from Front Office (FO) Departments. Then, results of FGD and survey were in a form of TLU both speaking and writing.

TLU of speaking consisted twenty six (26) items where eighteen (69\%) items were considered as TLUs for all hotels. They were as follows: addressing guests, asking guests' trip, asking about reservation to guests, explaining type of rooms to guests, asking about guests' room preference, asking about guests' length of stay, asking about additional service for the guests, responding to questions on tourism spots in the city, responding to questions on local food/culinary, responding to questions on directions, responding to guests' request on meeting room, asking the guest about preference of payment method, asking the guests on preference on currency for credit card payment of method, serving guests who wish to prolong their stay, serving the process of check out, serving the process of guests' payment, making small talks with guests, serving in-room check in of guests with special needs, and serving guests' complaints.

Meanwhile, TLU on asking about guests' purpose of visit, offering welcome drink, conducting courtesy call after the guests check-in received $88 \% .75 \%$ of the hotels admitted that asking the guest on preference on currency for credit card payment of method and giving morning call became their TLUs. Furthermore, only $50 \%$ of the hotels admitted offering guests as a hotel member and explaining facility as hotel member as the TLUs. Detailed TLUs of speaking can be seen below: 
Table 1: TLU of Speaking

\begin{tabular}{|c|c|c|c|}
\hline Skill & No. & TLU & Percentage \\
\hline \multirow{26}{*}{ 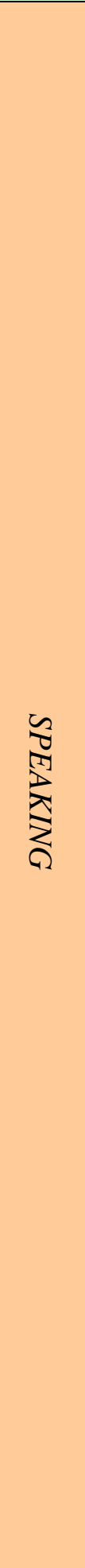 } & 1 & Address guests & $100 \%$ \\
\hline & 2 & Ask guests' trip & $100 \%$ \\
\hline & 3 & Ask about reservation to guests & $100 \%$ \\
\hline & 4 & Explain type of rooms to guests & $100 \%$ \\
\hline & 5 & Ask about guests' room preference & $100 \%$ \\
\hline & 6 & Ask about guests' length of stay & $100 \%$ \\
\hline & 7 & Ask about purpose of visit & $88 \%$ \\
\hline & 8 & Ask about additional service for guests & $100 \%$ \\
\hline & 9 & Respond to questions on tourism spots in Surabaya & $100 \%$ \\
\hline & 10 & Ask preference on drink and meals & $88 \%$ \\
\hline & 11 & Offer welcome drink & $88 \%$ \\
\hline & 12 & Respond to questions on local food/culinary & $100 \%$ \\
\hline & 13 & Respond to questions on direction & $100 \%$ \\
\hline & 14 & Respond to a request on meeting room & $100 \%$ \\
\hline & 15 & Ask the guest about preference on payment method & $100 \%$ \\
\hline & 16 & $\begin{array}{l}\text { Ask the guest on preference on currency for credit card } \\
\text { payment of method }\end{array}$ & $75 \%$ \\
\hline & 17 & Offer guests as a hotel member & $50 \%$ \\
\hline & 18 & Explain facility as hotel member & $50 \%$ \\
\hline & 19 & Serve guests who want to prolong the stay & $100 \%$ \\
\hline & 20 & conduct courtesy call after the guests check in & $88 \%$ \\
\hline & 21 & Do morning call & $75 \%$ \\
\hline & 22 & Serve the process of check out & $100 \%$ \\
\hline & 23 & Serve process of guests' payment & $100 \%$ \\
\hline & 24 & Make small talk with guests & $100 \%$ \\
\hline & 25 & Serve in-room check in of guests with special needs & $100 \%$ \\
\hline & 26 & Serve complaints & $100 \%$ \\
\hline
\end{tabular}


Besides speaking, results of FGD and survey to hotels showed TLUs of writing which have to be considered in designing TBECC. The agreed TLUs for receiving $100 \%$ acknowledgement by all were writing the details of guests' stay and guests' preference in details, writing internal emails to their superiors as problems that need special attention occurred, writing a division report to managers, writing apology letters when mistakes happened during guests' stay as well as responding guests' complaint.

\section{Target Language Use (TLO) of Writing}

Table 2: TLU of Writing

\begin{tabular}{|c|c|c|c|}
\hline Skill & No. & TLU & Percentage \\
\hline \multirow{10}{*}{ 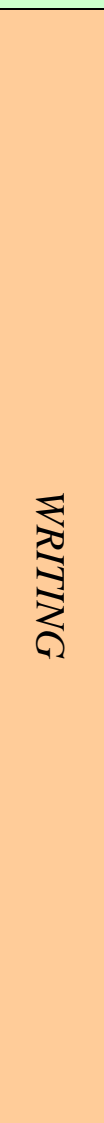 } & 1 & Writing the details of guests' stay & $100 \%$ \\
\hline & 2 & Writing guests' preference in details & $100 \%$ \\
\hline & 3 & $\begin{array}{l}\text { Write an internal email to their superiors when } \\
\text { facing a problem that need special attention }\end{array}$ & $100 \%$ \\
\hline & 4 & Write a division report to manager & $100 \%$ \\
\hline & 5 & $\begin{array}{l}\text { Write emails to other hotels which are under the } \\
\text { same group }\end{array}$ & $63 \%$ \\
\hline & 6 & $\begin{array}{l}\text { Write emails for coordination to other divisions at } \\
\text { the same hotel }\end{array}$ & $88 \%$ \\
\hline & 7 & $\begin{array}{l}\text { Write emails to guests for confirmation of their stay } \\
\text { before their coming }\end{array}$ & $75 \%$ \\
\hline & 8 & Write a thank you letter after the guest check-out & $63 \%$ \\
\hline & 9 & $\begin{array}{l}\text { Write an apology letter when mistake seem to } \\
\text { happen during the guests' stay }\end{array}$ & $100 \%$ \\
\hline & 10 & Respond guests' complaint & $100 \%$ \\
\hline
\end{tabular}

Based on the the Target Language Use (TLU) above, it can be broken down into tasks for each skill. For Speaking, several tasks should be designed as a part of TBECC will be (1) to describe a picture, (2) to express an opinion, (3) to propose a solution, (4) to summarize and re-tell information, (5) to respond to a statement, and (6) to formulate questions based on the information given. The criteria can be seen in table 3: 
Table 3: Breakdown of TLU for Speaking Skills

\begin{tabular}{|c|c|c|c|}
\hline Question & Task & Competence & Criteria \\
\hline 1 & Describe a picture & Describing room types & $\begin{array}{l}\text { Pronunciation } \\
\text { Grammar } \\
\text { Vocabularies }\end{array}$ \\
\hline $2-3$ & Express an opinion & $\begin{array}{l}\text { Explaining local } \\
\text { places and local } \\
\text { delicacies }\end{array}$ & $\begin{array}{l}\text { Pronunciation } \\
\text { Grammar } \\
\text { Vocabularies } \\
\text { Cohesion }\end{array}$ \\
\hline $4-7$ & Propose a solution & $\begin{array}{l}\text { Offering additional } \\
\text { services at the hotel } \\
\text { Offering welcome } \\
\text { drink } \\
\text { Offering solution for } \\
\text { complaints }\end{array}$ & $\begin{array}{l}\text { Pronunciation } \\
\text { Vocabularies } \\
\text { Cohesion } \\
\text { Relevance of the Context } \\
\text { Completeness of the } \\
\text { Context }\end{array}$ \\
\hline $8-9$ & $\begin{array}{l}\text { Summarize and } \\
\text { Re-tell } \\
\text { Information }\end{array}$ & $\begin{array}{l}\text { Asking about room } \\
\text { preferences }\end{array}$ & $\begin{array}{l}\text { Pronunciation } \\
\text { Relevance of the Context } \\
\text { Completeness of the } \\
\text { Context }\end{array}$ \\
\hline $10-12$ & $\begin{array}{l}\text { Respond to a } \\
\text { statement }\end{array}$ & $\begin{array}{l}\text { Greeting guests } \\
\text { Asking about the } \\
\text { reservation } \\
\text { Making small talk } \\
\text { Responding to a } \\
\text { complaint } \\
\text { Doing morning call }\end{array}$ & $\begin{array}{l}\text { Relevance of the Context } \\
\text { Pronunciation } \\
\text { Grammar }\end{array}$ \\
\hline $13-14$ & $\begin{array}{l}\text { Formulate } \\
\text { questions based on } \\
\text { the information } \\
\text { given }\end{array}$ & $\begin{array}{l}\text { Asking about food } \\
\text { preferences } \\
\text { Asking about the } \\
\text { payment method }\end{array}$ & $\begin{array}{l}\text { Pronunciation } \\
\text { Relevance of the Context } \\
\text { Grammar }\end{array}$ \\
\hline
\end{tabular}

For Writing, necessary task should be involved in the design will be as follows: 
Table 4: Breakdown of TLU for Writing Skills

\begin{tabular}{|l|l|l|l|}
\hline Question & Task & Competence & Criteria \\
\hline 1 & $\begin{array}{l}\text { Fill a form based on } \\
\text { the information } \\
\text { given }\end{array}$ & $\begin{array}{l}\text { Filling a detailed form } \\
\text { about a guest }\end{array}$ & Relevance of the Context \\
\hline $2-3$ & Write letters & $\begin{array}{l}\text { Writing a confirmation } \\
\text { letter } \\
\text { Writing a welcome } \\
\text { letter } \\
\text { Writing an email of } \\
\text { coordination }\end{array}$ & $\begin{array}{l}\text { Grammar } \\
\text { Relevance of the Context } \\
\text { Quality and variation of the } \\
\text { sentences } \\
\text { Vocabulary } \\
\text { Organization }\end{array}$ \\
\hline $4-5$ & Respond to written & $\begin{array}{l}\text { Replying a complaint } \\
\text { in written form } \\
\text { Writing a thank you } \\
\text { email }\end{array}$ & $\begin{array}{l}\text { Grammar } \\
\text { Relevance of the Context } \\
\text { Quality and variation of the } \\
\text { sentences }\end{array}$ \\
& & $\begin{array}{l}\text { Vocabulary } \\
\text { Organization }\end{array}$ \\
\hline
\end{tabular}

\section{Conclusion and Suggestions}

The absence of standard test for hotel industry in Surabaya, Indonesia will at least be able to create less competitive service in the respective area. More particularly, Front Office Division as the important front-liner should serve its best in order to achieve excellent service that lead to increasing rate of occupancy in hotels.

For this reason, a qualitative research involving stakeholders from hotels in Surabaya was conducted. Several stages of Focus Group Discussions were made in order to get Target Language Use (TLU) both for speaking and writing skills necessary to help Front Office staff in their daily basis operation with purpose of leaving positive image from customers staying at their hotels. To obtain detailed information and to make sure the TLU, the writer also distributed a set of questionnaire containing items of potential TLU on which all hotel practitioners gave their inputs.

Both FGD results and questionnaire finally gave 26 TLUs for speaking and 10 TLUs for writing. From which, the Test of Business English Communication Competence was designed. The criteria was also made in line with the expected outcome of the staff desired by the users. For better use of TBECC, the test was transformed into software version called 
TBECC 1.0 that shows the first version of the test. Additionally, in order to get more valid TLUs, bigger scope of participants is strongly suggested so detailed TLUc can be obtained to create better TBECC.

Not only a matter of much of time invested, this research also has another limitation; number of hotels involved as participants. The participants were only limited to two five-star hotels, four four-star hotels and two three-star hotels. The next research should involve fivestar hotels and more four-star hotels which can be the representative of hotel industries assumed as the most frequently English use at the FO department due to the fact that much bigger chance of accepting expatriates seeking for better hotel services.

It is also recommended that the test can have more relevant criteria in measuring speaking and writing competence of the FO candidates since not all elements in speaking and writing are needed based on the FO competence required on their daily basis performance. Furthermore, validity of test constructed shall be conducted to make sure the consistency of measurement and results of the test relevant to the FO competence.

\section{References}

Betchoo, N. K. (2017). The Impact of Industrial Placement on Students' Employability Skills in Tertiary Education. PEOPLE: International Journal of Social Sciences, 3(1), 199216. https://doi.org/10.20319/pijss.2017.31.199216

Datu, Y. (2016). Addressing English Speaking Competence to Face AEc 2015: A Suggested Collaboration with Vocational HIgh Schools. PICKS (p. 115). Bandung: Piksi Ganesha.

Datu, Y. (2016). Challenging Students' Confidence Level in English Presentation. The 63rd of Association of TEFLIN. Surabaya: Universitas PGRI Adi Buana.

Datu, Y. A., \& Rachmasari, D. (2016). Low English Proficiency of EFL Vocational Learners: Challenges and its Practical Solutions. NELTAL. Malang: Universitas Negeri Malang.

Ellis, M., \& Johnson, C. (1994). Teaching Business English. Oxford: Oxford University Press.

Graves, K. (2000). Designing Language Courses: A Guide for Teachers. Boston MA: Heinie Cengage.

Hadiyanto et al. (2017). Assessing Students and Graduates Soft Skills, Hard Skills and Competitiveness. PEOPLE: International Journal of Social Sciences, 3(2),, 18851906. https://dx.doi.org/10.20319/pijss.2017.32.18851906 
Hutchinson, \& Waters. (1996). English for Specific Purposes: a Learning Centered Approach. (1st ed.). Cambdridge:: CUP.

Mountford., A. (1981). The What, the Why and the Way. In: Aupelf/ Goethe Institut/ British Council, 19-34.

Richards, J. C., P, T., \& P, N. (1992). The Culture of the English Language Teacher: A Hongkong Example. RELC, 23 (1), 81-102.

https://doi.org/10.1177/003368829202300106

Soelistywati, E., \& Yuanti, E. E. (2016). Test of English for Vocational Students (TEVocS). Yogyakarta: Sekolah Vokasi Gadjah Mada.

Widdowson, H. (1981). ESP: Criteria for Course Design in Long, M.H. \& J.C. Richards (eds) Methodology in a Book of Readings. New York: Newbury House. 


\section{PEOPLE: International Journal of Social Sciences}

Home / About the journa

PEOPLE: International Journal of Social Sciences, is open access, peer-reviewed, and refereed journal.

The main objective of 'People' is to provide an intellectual platform for international researchers. 'People' aims to promote interdisciplinary studies in humanities and social science and become the leading journal in humanities and social science in the world. This journal is dedicated to the miracle called 'Society' that powers all types of civilizations and is fueled by the spirit of survival and co-existence.

\section{ISSN 2454-5899}

Editor-in-Chief

Assoc. Prof. Marek Matejun, Ph.D., D.Sc.,

Department of Entrepreneurship and Industrial Policy. Faculty of Management,

University of Lodz, Poland

Email: editor@grdspublishing.org

Scope of Journal

The journal aims to publish inter-disciplinary articles from the field of Social Science \&. Humanities such as:
- Language
- Literature
- Education
- Philosophy
- Culture \& Society
- Business \& Socio-Economics
- Legal Studies
- Developmental Studies 


\section{Editor-in-Chief}

Assoc. Prof. Marek Matejun, Ph.D. D.Sc., Department of Entrepreneurship and Industrial Policy, Faculty of Management. University of Lodz, Poland

\section{Former Editor-in-Chief}

Dr. Merissa Braza Ocampo, Professor, Fukushima Gakuen University, Jaepan

\section{Managing Editor}

Dr. Davis Lazarus, Global Research \& Development Services Publishing

\section{Editorial Board}

Dr. Yang Yicheng, Associate Professor, (Ph.D.) National Taiwan University of Arts (MFA) The School of Dance, Korea National University of the Arts, Seoul, South Korea

Oyeniyi Toluwalope Olubukola, French Language Lecturer, Foreign Languages Unit, College of Social and Management Sciences, Afe Babalola University, Ado Ekiti, Ekiti State, Nigeria, West Africa

Dr. Sachin Gupta, Assistant Professor, Department of Business Administration, Mohanlal Sukhadia University, Udaipur [Rajasthan], India

Prof. Dr. Selcuk Kendirli, Hitit Üniversitesi IiBF Department of Banking and Finance, Turkey.

Dr. Nassef Manabilang Adiong. Institute of Islamic Studies, University of the Philippines Diliman, Philippines

Dr. Noor Hanim Rahmat, Associate Professor, Academy of Language Studies, Universiti Teknologi Mara, 40450 Shah Alam. Selangor Darul Ehsan, Malaysia

Dr. Hend Mohamed Abdel Rahman, Associate Professor of Egypt's Modern \& Contemporary History, Minia University. Egypt

Gita Widya Laksmini Soerjoatmodjo, M.A. M.Psi, Psikolog. Universitas Pembangunan Jayą, Tangerang Selatan, Banten. Indonesia

Mariwan Nasradeen Hasan Barzinji, English Department, School of Basic Education, University of Sulaimani. Sulaymaniyah, Kurdistan Region, Irag

Seri Hartati, Head of Treasury Department, Universitas Abdurrab, Pekanbaru, Indonesia

Dr. Dahlia Romero Domingo, Faculty, Language Department, New Era University, Quezon City, Philippines

Malini Nair, Business Faculty_(Lecturer), Business Department, Higher Colleges of Technology, Sharjah, UAE

Gechun Lin, Department of Political Science, School of Art and Science, Washington University, St. Louis, Missouri, USA

Wasim Akram, Lecturer, Department of Economics, Faculty of Arts and Social Sciences, Hamdard University Bangladesh. Bangladesh 
Joanna Tan Tjin Ai, Lecturer, Department of Languages and Linguistics, Faculty of Arts and Social Science, Universiti Tunku Abdul Rahman, Petaling Jaya, Malaysia

Dr. Pradipta Shyam Chowdhury, Assistant Professor of English, North Bengal University, Raja Rammohunpur, DtDarjeeling. India

Dr. Fahmeeda Gulnaz, Assistant Professor, Celta, IH, Johannesburg, South Africa, (Cambridge ESOL Examinations), Taif University, Taif, Kingdom of Saudi Arabia

Dr. Yoshiko Yamaguchi, RN, Ph.D. Research Associate of Home Care Nursing, Faculty of Nursing, Kwassui Women's University, Nagasaki, Japan

Zarin Tasnim, Lecturer, Department of English, Shahjalal University of Science and Technology, Sylhet, Bangladesh Md. Shamsuddoha, Senior Faculty Member, Emergence of Bangladesh, Brac University, Bangladesh 
Home / Archives / Vol 5 No 1 (2019): Regular Issue

Published: $2019-03-15$

Articles

THE IMPACT OF AUTOMATION TOWARDS FEMALE LABOR FORCE IN INDONESIA AND THE ATTEMPTS TO ESTABLISH BETTER PROTECTION MECHANISM

Dominique Virgil

즈 PDF

STRESS AND COPING STRATEGIES AMONG PARENTS OF CHILDREN WITH AUTLSM SPECTRUM DISORDER

Mona H Mostafa

Q PDF

CONFIRMATORY FACTOR ANALYSIS OF LATENT SUB-SCALES OF TEACHER RESEARCH ENGAGEMENT OF PUBLIC SCHOOLS ELEMENTARY TEACHERS

H. L. Langam

요 PDF

EMPOWERING WOMEN: HOW SHOULD THE DMANI STATE CONTINUE SUPPORTING WOMEN WORKING IN ITS HANDICRAFTS INDUSTRIES?

Humaira Hansrod

D PDF

THE DESIGN OF TBECC (TEST OF BUSINESS EVGLISH COMMUNICATION COMPETENCE) FOR FRONT OFFICE STAFF IN HOTEL INDUSTRY: A CASE STUDY OF HOTELS IN SURABAYA, INDONESIA

Yerly A. Datu, Singgih Widodo Limantara, Endang Soelistiyowati, Tofan Dwi Hardjanto, Yusron Fuadi

R PDF

LOCAL COMMUNITY PARTICIPATION IN ECOTOURISM DEVELOPMENT: THE CASE OF SUMBERWANGI HAMLET DESTINATION, EAST JAVA, INDONESIA

Novi Sunu Sri Giriwati, La Choviya Hawa, Sigmawan Tri Pamungkas, Wasiska lyati, A. R. Taufiq Hidayat

D PDF

EFFECTS OF OUTDOOR GAME ACTIVITIES ON ABILITY OF FINE MOTOR USAGE FOR EARLY CHILDHOOD

Wunwisa Muangthong

D PDF

THE EFFECTS OF EVIDENCE-BASED PRACTICE (EBP) AND REFLECTIVE TEACHING ON THE EBP ABILITY OF NURSING STUDENTS

Khanarot Apinyalungkon, Sutthida Ornlaor

Q PDF 
MANAGERS' PERSONALITY PREFERENCES, MANAGERIAL STYLES AND EMPLOYEE SATISFACTION OF MULTINATIONAL COMPANIES: AN INPUT TO HUMAN RESOURCE STRATEGIC PLAN

Chester Alexis C. Buama

圆 PDF

A STUDY ON DEVELOPMENT AND CURRENT APPLICATION OF MOTION GRAPHIC IN TAIWAN'S POPULAR MUSIC

Chia Min Chen, Yen Jung Chang

124-134

D PDF

FUNCTIONAL ANALYSIS OF MOVIE CHARACTERS: THE CASE OF THE TAG-ALONG

Wei Ting Hsieh, Yen Jung Chang

$135-145$

요 PDF

TOWARDS AN EQUITABLE AND LIBERAL SOCIETY: 2OTH CENTURY LITERARY CRITICISM AND THEORIES

Manjit Kaur

$146-154$

圆 PDF

JOB SATISFACTION AMONG ACADEMIC STAFF IN THE PUBLIC UNIVERSITIES OF THAILAND

Sarunya Tarat, Manassaphorn Wongsawat

$155-168$

圆 PDF

RETHINKING AND REPOSITIONING THE UNIVERSITY AS CADRE AND ACTIVIST FOR THE POST-APARTHEID STATE:

EVIDENCE FROM RURAL SOUTH AFRICA

Mavhungu Abel Mafukata

$169-177$

[ $\mathrm{PDF}$

BETWEEN FISHING, MINING, AND SUCTION VESSEL: THE COMPROMISE OF TELUK LIMAU PEOPLE, WEST BANGKA, ON TIN MINING AGGRESSION

Ibrahim, Dwi Haryadi, Nanang Wahyudin

$178-185$

R PDF

THE DISCOURSE OF GOVERNANCE IN THE LINGUISTIC LANDSCAPE OF QUEZON CITY GOVERNMENT Jaybee G. Coronel

国 PDF

ASSESSMENT ON DIMENSIONS OF AUTHENTIC LEADERSHIP OF COLLEGE TEACHERS

Rose A. Arceño, Saiffullah Idris M. Ag. Tanimu Ibrahim Adamu

R PDF

CZECH ACADEMIC ETIQUETTE

Lada Hanzelinova

종 PDF

HOUSEHOLDS' WILLINGNESS TO PAY FOR IMPROVED DRINKING WATER-A CASE STUDY ON KHULNA CITY CORPORATION USING DISCRETE CHOICE MODEL

Wasim Akram, Md. Touhidul Alam

圆 PDF 
EVALUATION THROUGH E-GOVERNANCE IN EDUCATION

Saadia Kashif, Rabea Saeed

B PDF

INTERNATIONAL RESPONSIBILITY OF THE ISRAELI AGGRESSION ON GAZA STRIP IN 2014

Mohammed R. M. Elshobake

$827-845$

R PDF

ENVIRONMENTAL DECISION-MAKING THROUGH ADJUDICATORY APPEALS IN THE UNITED STATES

Kelly Tzoumis, Emma Shibilski

$846-865$

国 PDF

THE MODERATING ROLE OF TRAINING ON THE RELATIONSHIP BETWEEN STRATEGY MANAGEMENT, INFORMATION TECHNOLOGY MANAGEMENT AND ORGANIZATIONAL PERFORMANCE OF SHARJAH POLICE

Abdulla Awadh Abdulla Abdulhabib, Hassan Saleh Al-Dhaafri

因 PDF

THE USE OF ADVENTURE BOOKS IN FOSTERING CHILDREN'S LANGUAGE SKILL

Steffany Cleryica Harry, Hariany Mohd Hassan, Aisyah Bin Elian, Mary Gorrete Bte Valintine, Sirhajwan Idek

B PDF

DEVELOPING SOFT SKILLS THROUGH GAMIFIED ENGLISH LANGUAGE ACTIVITIES (ZOMBIE CHALLENGE SERIES)

Sirhajwan Idek

오 PDF

SCHOOL ENTERPRISE: NURTURING STUDENTS' ENTREPRENEURIAL SKILLS THROUGH SALES BOOTH

Dydinelynn Dydimus, Sunarti Nur Amirah Masli, Sirhajwan Idek

R PDF

APPLICATION OF PLACEBO EFFECT INTERFACE DESIGN IN IMPROVING THE USER EXPERIENCE

Shao Feng Wang

$913-924$

国 PDF

A NEW MODEL FOR ONLINE FOOD ORDERING SERVICE BASED ON SOCIAL NEEDS IN A SHARING ECONOMY Ningchang Zhou, Lai Chung Lee

国 PDF

STUDY ON THE PREFERENCE OF SENIOR CITIZENS IN URBAN PARK PUBLIC FACILITIES

Tian-Yang Huang. Chiwu Huang

$938-951$

国 PDF

USING HEURISTIC STRATEGIES TO PROMOTE MATHEMATICS PROBLEM SOLVING ABILITY OF GRADE 10 STUDENTS Attakan Vongyai, Tipparat Noparit

国 PDF 